\title{
HYBRID BRIDGE STRUCTURES MADE OF FRP COMPOSITE AND CONCRETE
}

\author{
Mateusz RAJCHEL ${ }^{1}$, Tomasz SIWOWSKI \\ Rzeszów University of Technology, Rzeszów, Poland
}

\begin{abstract}
Despite many advantages over the conventional construction materials, the contemporary development of FRP composites in bridge engineering is limited due to high initial cost, low stiffness (in case of glass fibers) and sudden composite failure mode. In order to reduce the given limitations, mixed (hybrid) solutions connecting the FRP composites and conventional construction materials, including concrete, have been tested in many countries for 20 years. Shaping the hybrid structures based on the attributes of particular materials, aims to increase stiffness and reduce cost without losing the carrying capacity, lightness and easiness of bridges that includes such hybrid girders, and to avoid the sudden dangerous failure mode. In the following article, the authors described examples of hybrid road bridges made of FRP composite and concrete within the time of 20 years and presented the first Polish hybrid FRP-concrete road bridge. Also, the directions of further research, necessary to spread these innovative, advanced and sustainable bridge structures were indicated.
\end{abstract}

Keywords: FRP composite, concrete, hybrid structures, bridges, shaping

\section{INTRODUCTION}

The structural FRP (fibre reinforced polymer) composites used to construct bridge structures are one of the modern solutions in bridge construction industry. Due to their excellent attributes, as e.g. high ultimate strength, high overall durability, corrosion resistance and low weight (lightness), the FRP composites are considered high-value construction material, just as steel and concrete, and taken

\footnotetext{
${ }^{1}$ Corresponding author: Rzeszow University of Technology, Faculty of Civil and Environmental Engineering and Architecture, Poznańska st 2, 35-959 Rzeszów, Poland, e-mail: mrajchel@prz.edu.
} 
into account in bridge design and construction industry [1]. However, despite many advantages of fibre reinforced polymers over the conventional construction materials, the use of FRP composites in bridge construction industry is limited to two areas: repair and strengthening the existing structures and redecking of deteriorated deck slabs. The main reasons of such a limited use are high initial cost of FRP composites, low stiffness of structural elements made mainly of fibreglass (GFRP - glass fibre reinforced polymers), and sudden composite failure mode, which is unacceptable in bridge engineering. Whereas the initial cost issue may be soon solved due to mass and automated production of FRP composite elements, the problem of lack of stiffness and safe failure mode may be overcome only by implementing innovative design solutions [2].

In order to reduce the given limitations, mixed (hybrid) solutions connecting the FRP composites and conventional construction materials, including concrete, have been tested in many countries for 20 years. The construction of a hybrid girder consists of a composite box I-beam (with single- or double-chamber) or a round beam, and concrete slab, which serves as a bridge deck. Rigid combination of these both elements ensures the safe carrying of loads. The main aim of creating the hybrid structures is to combine different materials, so that their best attributes are used optimally. That is why, different construction materials are applied in the hybrid girders in order to carry tension, compression and shear generated in a structure exposed to loads.

Initial research and first prototypical applications proved that combining the FRP composites and concrete is a very effective solution in road bridge construction industry [3], [4]. Evolution of shaping the „FRP composite-concrete” hybrid bridge girders within the time of 20 years was described in the authors' previous paper [5]. Whereas, in this article, the basic rules of shaping the hybrid girders destined for road bridge construction were laid down together with their chosen applications in bridge spans. Also, case of a first Polish road bridge with hybrid girders was described in this paper. The conclusions consist of directions of further research, which is necessary to spread these innovative, advanced and sustainable bridge structures.

\section{EXAMPLES OF HYBRID ROAD BRIDGES}

The construction of a first hybrid road bridge resulted from repair actions taken after the first FRP composite bridge built in Miyun, China, in 1982, was damaged. Few years after the bridge had been opened to traffic, a FRP composite sandwichstructured slab span was reinforced by additional concrete layer placed on the top of the slab and bonded with the FRP composite to provide synergy of both materials. On the occasion of the given repair actions, the research was carried out, showing that the hybrid structure performs well and the idea of combining 
the FRP composite with concrete in bridge spans is promising and development worthy [4].

One of the first examples of a road bridge, where the hybrid girders made of rectangular GFRP profiles were used intentionally, is a construction in Toowoomba, Australia [6]. The bridge was built in 2002 and is the first FRP composite bridge in Australia. A single-span slab construction with span of $12 \mathrm{~m}$ and width of $5 \mathrm{~m}$ consists of $0,35 \mathrm{~m}$ and $0,10 \mathrm{~m}$ high composite rectangular beams and $0,10 \mathrm{~m}$ thick prefabricated concrete slab. The composite beams and the concrete slab were glued together with an epoxy adhesive. In order to ensure the required stiffness and cross synergy of spans, CFRP laminates were glued on the bottom of the spans crosswise (Fig. 1). The bridge span is made of two identical 2,50 m wide elements that consist of 7 composite beams. Both elements are bonded together with a longitudinal joint. The whole span weights less than 20 tonnes. A few bridges like this were built in Australia and recently the technology has been applied in the United States.

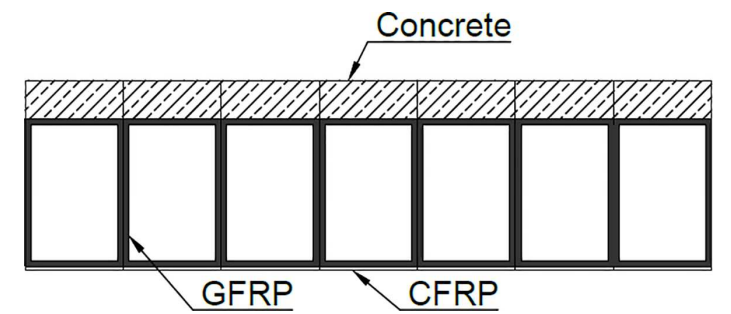

Fig. 1. Cross section of the bridge span in Toowoomba, Australia

The hybrid girders in form of the concrete-filled FRP tubes (CFFT) were firstly used in 2000 while constructing Kings Stormwater Channel Bridge, California, the USA [7]. Bridge is a double-span, continuous construction with an effective span of $2 \times 10,05 \mathrm{~m}$. Bridge spans are made of composite CFRP tubes filled with concrete and integrated with deck slab, which in turn consists of $0,18 \mathrm{~m}$ thick composite panels. Overall width of the deck amounts 13,00 m. There are six CFFT girders visible in the cross section, each one with the diameter of $0,34 \mathrm{~m}$ and cross span of 2,30 m (Fig. 2). CFFT girders are connected with both abutments and pillars by means of concrete ties and steel anchors. The other bridge of the same type, was equipped with the conventional reinforced-concrete slab integrated with the CFFT girders, instead of the deck slab made of composite panels [3]. The same technology was used in engineering many arch bridges with span of 10-15 $m$ and consisting of dozen of hybrid girders [8]. 


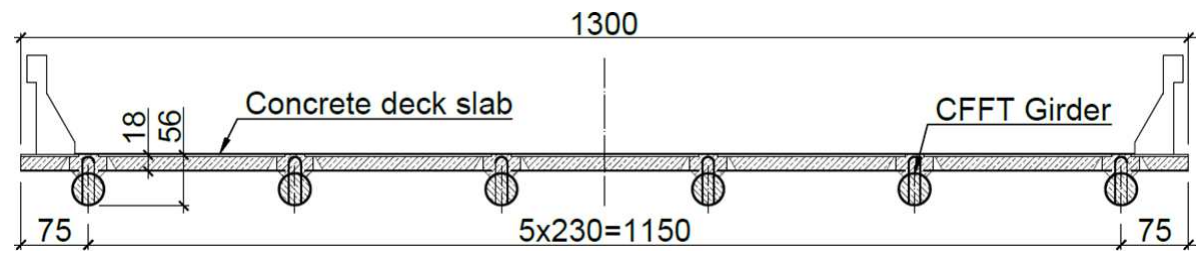

Fig. 2. Cross section of Kings Stormwater Channel Bridge span, USA [cm]

The first beam bridge made of hybrid U-beams was built in 2004 in San Patricio County, Texas, the USA [9]. The bridge is a double-span construction with span of $2 \times 9,75 \mathrm{~m}$. Overall width of the deck is $9,10 \mathrm{~m}$. Each span consists of 12 hybrid girders with an axial span of $0,81 \mathrm{~m}$ (Fig. 3). Deck slab is made of regular concrete reinforced by steel bars.

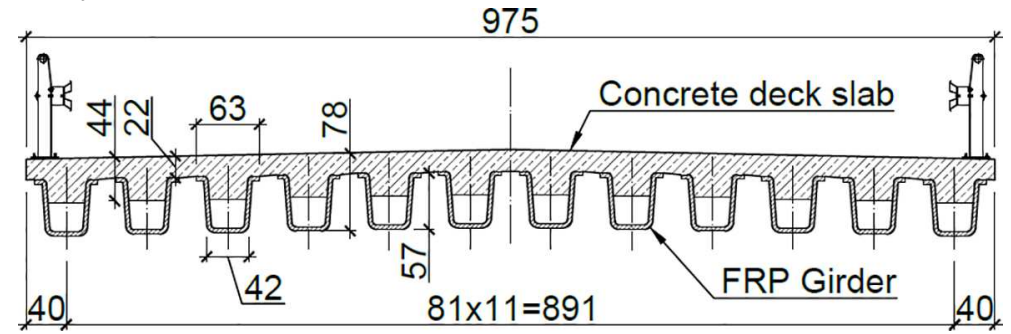

Fig. 3. Cross section of the bridge span in San Patricio Country, USA [cm]

The first bridge, in which unconventional hybrid HBC girders were used, is the Knickerbocker Bridge built in 2010 in Boothbay, Maine, the USA [10]. The bridge has eight spans with deck length and width amounting accordingly $164 \mathrm{~m}$ and 9,73 $\mathrm{m}$. The first and last span is $18,2 \mathrm{~m}$ long, whereas six middle spans are $21,3 \mathrm{~m}$ long. In the span cross section, there are 8 hybrid-composite beams with height of $0,84 \mathrm{~m}$ and width of 1,22 $\mathrm{m}$ (top flange) (Fig. 4). Each beam is reinforced by one layer of steel bars with the diameter of $12 \mathrm{~mm}$. On the beams, there is a conventional concrete slab, reinforced by steel bars and integrated with hybridcomposite beams by means of bolts. The Knickerbocker Bridge is probably the longest bridge in the world, which girders were mainly made of FRP composites.

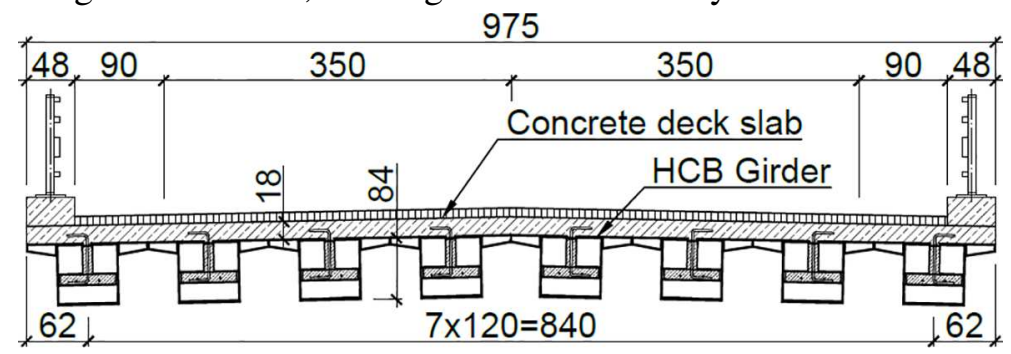

Fig. 4. Cross section of the Knickerbocker Bridge span, Boothbay, USA [cm] 
In 2004, a first European hybrid bridge was built over the Cantabrico motorway in Asturias, Spain [11]. The overpass includes $46 \mathrm{~m}$ long four-span continuous beam, each of spans is accordingly 10,13,13 and $10 \mathrm{~m}$ long. Total width of the deck amounts 8,00 m. Each span consists of three hybrid closed trapezoidal girders with an axial span of $2,75 \mathrm{~m}$. Construction height of the span amounts 1,00 m (Fig. 5). The composite box beams are filled with foam and integrated with $0,15 \mathrm{~m}$ thick reinforced-concrete deck slab by means of composite profiles glued to the top surface of the beams.

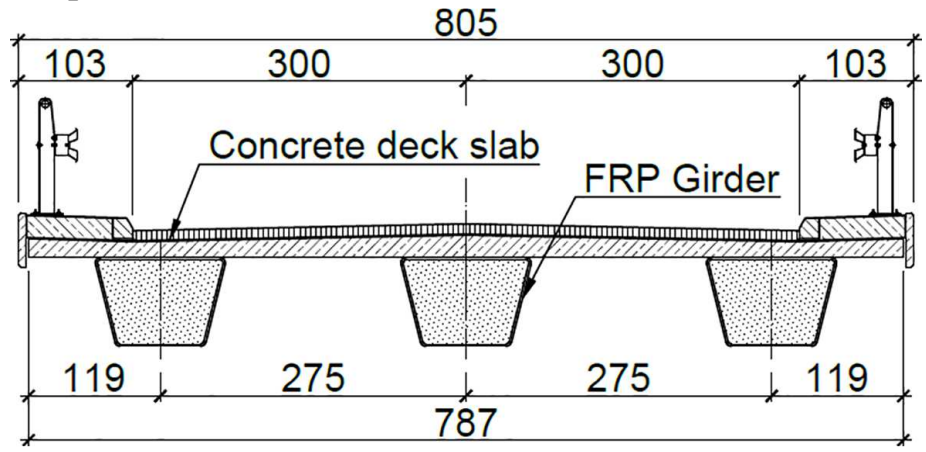

Fig. 5. Cross section of span of the Cantabrico motorway overpass, Span [cm]

Other constructions with the hybrid girders are two identical bridges built over the M111 motorway in 2007 in Madrid [12]. Each of the overpasses has 34 long three spans, each of spans is accordingly 10, 14 and $10 \mathrm{~m}$ long. Total deck width amounts $20,40 \mathrm{~m}$. The span consists of four hybrid GFRP/CFRP open box girders with height of 1,20 m. The composite box girders are integrated with the $0,30 \mathrm{~m}$ thick reinforced-concrete deck slab by means of steel bolts and epoxy glue. The composite sandwich panels were used as a permanent shuttering placed below the concrete slab, both inside and outside the girders (Fig. 6).

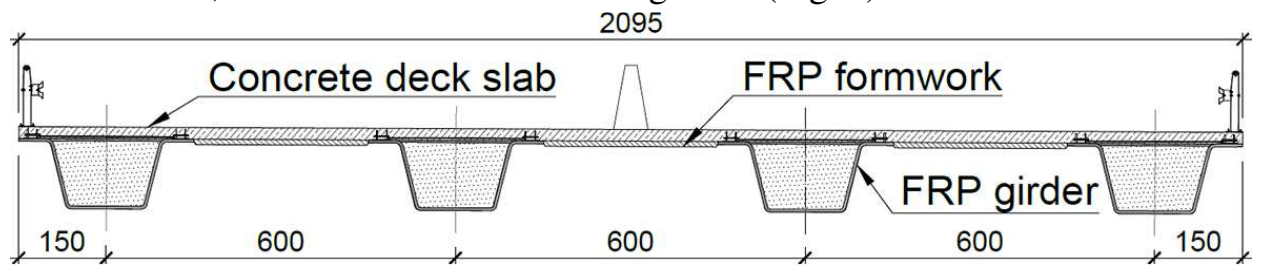

Fig. 6. M111 motorway overpass in Madrid, Span [cm]

\section{FIRST POLISH ROAD BRIDGE MADE OF FRP COMPOSITE AND CONCRETE}

First Polish hybrid bridge made of FRP composite and concrete was built in Błażowa near Rzeszów by the Ryjak river along the district road No 1411R. The 
construction replaced a former steel truss bridge with wooden deck slab, which low carrying capacity, narrow carriageway and bad technical condition had caused considerable traffic limits. The new bridge is a statically determinate single-span construction with a longitudinal gradient amounting $1 \%$. The main technical-geometric parameters are as follows:

- carrying capacity: B-class according to PN-85/S-10030, that is 40 tonnes;

- effective span: $21,00 \mathrm{~m}$;

- total bridge length: $22,30 \mathrm{~m}$;

- total bridge width: $10,54 \mathrm{~m}$;

- deck width: carriageway $7,00 \mathrm{~m}(2 \times 3,50 \mathrm{~m})$, hard strips $2 \times 0,50 \mathrm{~m}$, one-side pavement $1,50 \mathrm{~m}$, railing with ledge $2 \times 0,52 \mathrm{~m}$.

Hybrid bridge span is made of four FRP composite box girders integrated with lightweight concrete deck slab (Fig. 7). The FRP girders are braced by two reinforced-concrete cross beams, situated at the bridge ends, that are monolithic with the deck slab. The slab with constant thickness of $0,18 \mathrm{~m}$ is made of a LC 35/38 class lightweight concrete reinforced by two sets of netted GFRP composite bars with diameter of $12 \mathrm{~mm}$. The slab is integrated with the composite girders by means of bolts, placed in the top flanges of composite girders, and epoxy glue. In the same way, the composite and concrete were integrated in support section of the span. The span is equipped with conventional asphalt road pavement and insulation, elements of drainage, expansion joints and bridge barriers. Bridge supports consist of reinforced concrete integral abutments, placed on deep foundation. In view of bedded subgrade, the deep foundation was designed in form of bored piles with diameter of $0,60 \mathrm{~m}$ and length of $8,00 \mathrm{~m}$, moulded in the ground. Each abutment is placed on 10 piles.

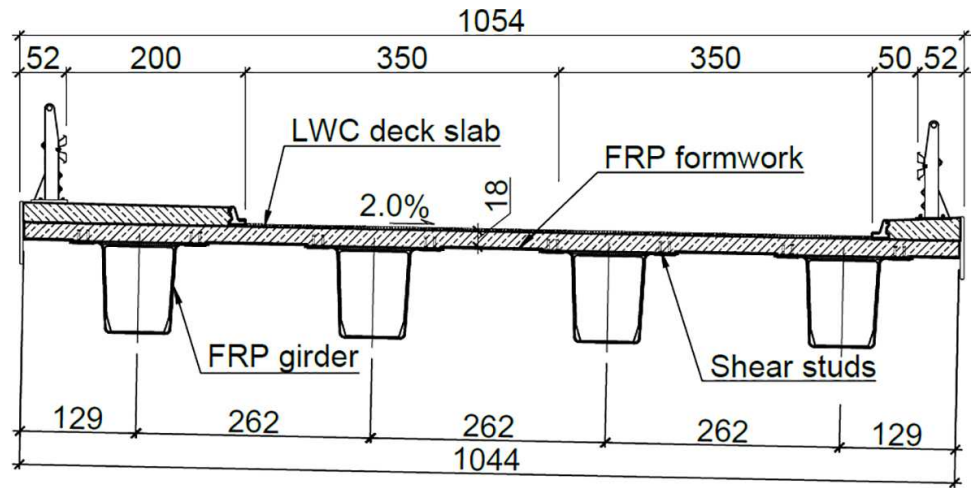

Fig. 7. Cross section of the hybrid bridge in Błażowa, Poland [cm]

Figure 8 shows the bridge opened to traffic, whereas detailed description of bridge construction and used technology is available in the paper [13]. 


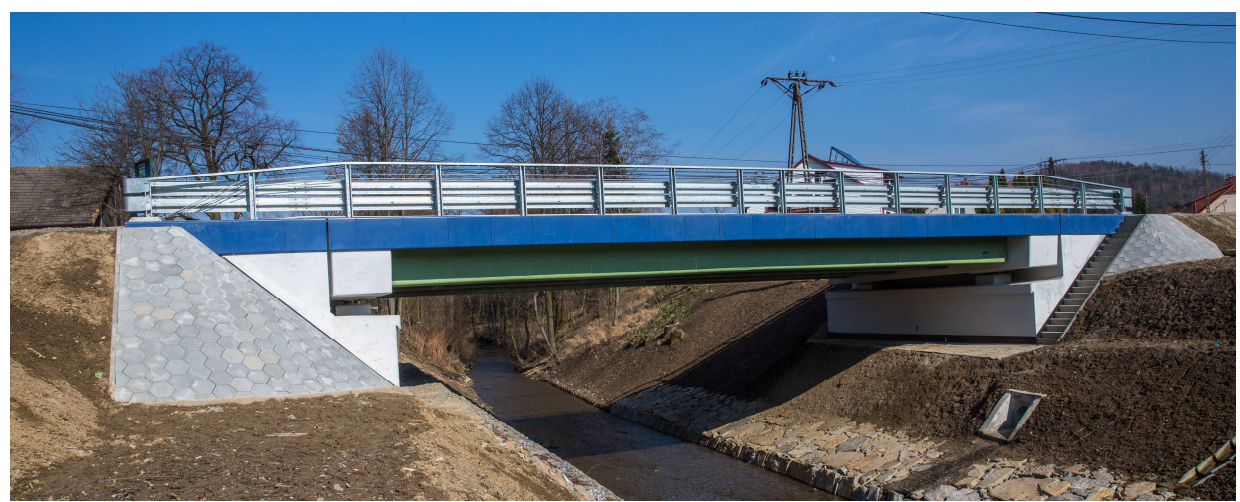

Fig. 8. Hybrid bridge made of FRP composite and concrete in Błażowa opened to traffic, Poland

\section{CONCLUSIONS}

Hybrid bridges, in which the advantages of FRP composite and concrete were intentionally combined, are currently one of the fastest developing bridge construction types. The reason is that the well-known attributes of FRP composites, such as overall durability, ultimate strength and lightness together with characteristics of concrete, e.g. stiffness, low cost and quasi-plastic failure mode, were successfully combined. This clever combination applied in hybrid bridge engineering may soon result in the use of hybrid bridge spans as a part of public roads being more and more popular in high-developed countries. However, in order to fully convince the public authorities of its use legitimacy, it is necessary to continue the research on particular types of hybrid girders and performance of bridges that include such girders after opening to traffic. In further research, the following issues should be explained:

- carrying capacity, overall durability and failure mechanism of connection between the composite and concrete (mechanical, glue joint);

- performance of the hybrid girders over time (fatigue, creep, environment influence);

- performance of the hybrid girders under load or accidental actions (hitting, fire);

- effective non-destructive testing (NDT) and structural health monitoring (SHM) of the hybrid bridges;

- designing guidelines and maintenance regulations,

- werification and walidation FEM model. 


\section{ACKNOWLEDGMENTS}

The paper was created within the scope of the project named „COM-BRIDGEInnovative Road Bridge Made of FRP Composites". The project has been carried out within a pilot „DEMONSTRATOR + Supporting scientific research and development works in demonstration scale" (agreement No UOD-DEM-1-0411001) and has been co-financed by the National Centre for Research and Development.

\section{REFERENCES}

1. Hollaway L.C.,Head P.R.: Advanced polymer composites and poly-mers in the civil infrastructure. Elsevier, Oxford, 2001.

2. Zoghi M. (ed.): 2014. The International Handbook of FRP Composites in Civil Engineering. CRC Press, Taylor \& Francis Group LLC, Boca Raton.

3. Cheng L., Karbhari V.M.: New bridge systems using FRP composites and concrete: a state-of-the-art review. Progress in Structural Engineer-ing and Materials, Vol.8, No. 4, pp. 143-154, 2006.

4. Yang L.: Research status of FRP-concrete composite beam/bridge deck systems. Applied Mechanics and Materials, Vols. 587-589, pp. 1424-1429, 2014.

5. Siwowski T., Rajchel M.: Ksztattowanie mostowych dźwigarów hybrydowych typu , kompozyt FRP - beton”. Czasopismo Inżynierii Lądowej, Środowiska i Architektury / Journal of Civil Engineering, Environment and Architecture, tom XXXIII, zeszyt 63 (nr 1/I/2016), styczeń - marzec, p. 307-320, 2016.

6. Van Erp G., Cattell C., Heldt T.: Fibre composite structures in Australia's civil engineering market: an anatomy of innovation. Progress in Structural Engineering and Materials, Vol.7, No.3, pp.150-160, 2005.

7. Seible F., Karbhari V.M, Burgueño R.: Kings Stormwater Channel and I-5/Gilman Bridges, USA. Structural Engineering International, Vol.9, No.4, pp. 250-253, 1999.

8. Dagher H. J., Bannon D. J., Davids W.G., Lopez-Anido R.A., Nagy E., Goslin K. 2012: Bending behaviour of concrete-filled tubular FRP arches for bridge structures. Construction and Building Materials, Vol.37, pp.432-439.

9. Ulloa F.V., Medlock R.D., Ziehl P.H., Fowler T.J.: Hybrid bridges in Texas. Concrete International, Vol.26, No.5, pp. 38-43, 2004.

10. Maine Bridge employs hybrid-composite beam technology:: Reinforced Plastics, July/August, pp.18-19, 2011.

11. Mires J., Calvo I., Pineda L., Botello F., Gomez M., Primi S., Bonilla J.: First bridge constructed of carbon fibre reinforced polymers in Spain. Proceedings of the FRPRCS-8, Patras, Greece, pp.596-597, 2007. 
12. Areiza-Hurtado M., Bansal A., Paulotto C., Primi S.: FRP girder bridges: lessons learned in Spain in the last decade. Proceedings of CICE. The 6th International Conference on FRP Composites in Civil Engi-neering, Rome, Italy, 2012.

13. Siwowski T., Rajchel M., Kaleta D., Własak L.: Pierwszy w Polsce most drogowy z kompozytów FRP. Inżynieria i Budownictwo, nr 10, rok LXXII, p.534-538, 2016.

\section{MOSTOWE KONSTRUKCJE ZESPOLONE TYPU “KOMPOZYT FRP - BETON"}

\section{Streszczenie}

Pomimo wielu przewag w stosunku do konwencjonalnych materiałów budowlanych, współczesny rozwój zastosowań kompozytów FRP w budownictwie mostowym jest ograniczony ze względu na wysoki koszt początkowy, zbyt małą sztywność oraz nagłą postać zniszczenia elementów konstrukcyjnych. W celu redukcji tych ograniczeń od blisko 20 lat w wielu krajach testuje się rozwiązania mieszane (hybrydowe - zespolone), łączące kompozyty FRP z konwencjonalnymi materiałami budowlanymi, w tym głównie $\mathrm{z}$ betonem. Kształtowanie konstrukcji hybrydowej, bazujące na właściwościach poszczególnych materiałów składowych, ma na celu zwiększenie sztywności i redukcję kosztów, bez utraty nośności, lekkości i łatwości budowy mostów z takich dźwigarów oraz uniknięcie nagłej, niebezpiecznej postaci zniszczenia. W artykule przedstawiono przykłady mostów drogowych o konstrukcji hybrydowej z kompozytów FRP i betonu na przestrzeni ponad 20 lat oraz pierwszy polski most drogowy o konstrukcji hybrydowej „kompozyt FRP - beton”. Wskazano także kierunki dalszych badań, niezbędnych w celu upowszechnienia tych innowacyjnych konstrukcji mostowych.

Słowa kluczowe: kompozyt FRP, beton, konstrukcja zespolona, most, kształtowanie

Editor received the manuscript: 1.07.2017 